\title{
Environmental Effect of Using Polluted Water in New/Old Fish Farms
}

\author{
Y. Hamed ${ }^{1}$, Sh. Salem ${ }^{2}$, A. Ali ${ }^{3}$ and A. Sheshtawi ${ }^{1}$ \\ ${ }^{1}$ Civil Engineering Department, Faculty of Engineering, Port Said University \\ ${ }^{2}$ Ministry of Water Resources and Irrigation \\ ${ }^{3}$ Irrigation and Hydraulics Department, Faculty of Engineering, Ain Shams University, \\ Egypt
}

\section{Introduction}

One of the most dangerous hazards affecting the environment situation in arid and semiarid countries like Egypt is the water and soil pollution. Due to the lack of fresh water for irrigation, countries in arid and semi arid areas are forced to use marginal waters for irrigation and raising fish. The effect of using such kind of low quality water is rather dangerous on the environmental situation. Besides, countries like Egypt are facing great problems to get rid of untreated waste water and industrial disposal in addition to drainage water. The spill of such kind of waters in drains and lakes will cause great problems to the eco-system and environment in general. What will make the problem more complicated is the use of these waters for irrigation or raising fish due to lack of fresh waters. The using of polluted water in fish farms has a very dangerous environmental effect on soil and ground water. The water level in fish farms is higher than the original land level. Consequently, water flows from fish farms to the adjacent land and cause problems if the water was polluted.

Bahr El-Baqar drain is considered as one of the most polluted drains in Egypt (Abdel-Shafy \& Aly 2002). It receives and carries the greatest part of wastewater (about 3 BCM/year) into Lake Manzala through a very densely populated area of the Eastern Delta passing through four highly populated Governorates. Unfortunately, at the last decades, great areas on both sides of the drain were using its polluted water for irrigation and raising fish. As a polluted drain with high risk to the surrounding environment, Bahr El Baqar has received considerable concern by many scientists. Ali et al. (1993), Abdel-Azeem et al. (2007) studied the effect of prolonged use of drain water for irrigation on the total heavy metals content of south Port-Said city soils. They found that using such kind of water will cause high concentration of heavy metals in soil and plants roots and shots. Water quality, chemical composition, and hazardous effects on Lake Manzala water and living organisms caused by Bahr El-Baqar drain water has also been studied by several investigators like: Rashed \& Holmes (1984), Khalil (1985) and Ezzat (1989). Special attention has been paid to the effect of environmental pollution from microbiological and toxicological points of view (Zaki 1994).

Fish farms located on both sides of the Bahr El-Baqar drain are using the polluted water for rising fish since long time ago. Furthermore, many agricultural lands located in these areas are also using such kind of water for irrigation. The hazardous of such kind of water on 
environment is enormous. Not to mention to the fish itself coming from these farms. The fish production from these farms goes directly to the market. Consequently, the risk to the human health is very high.

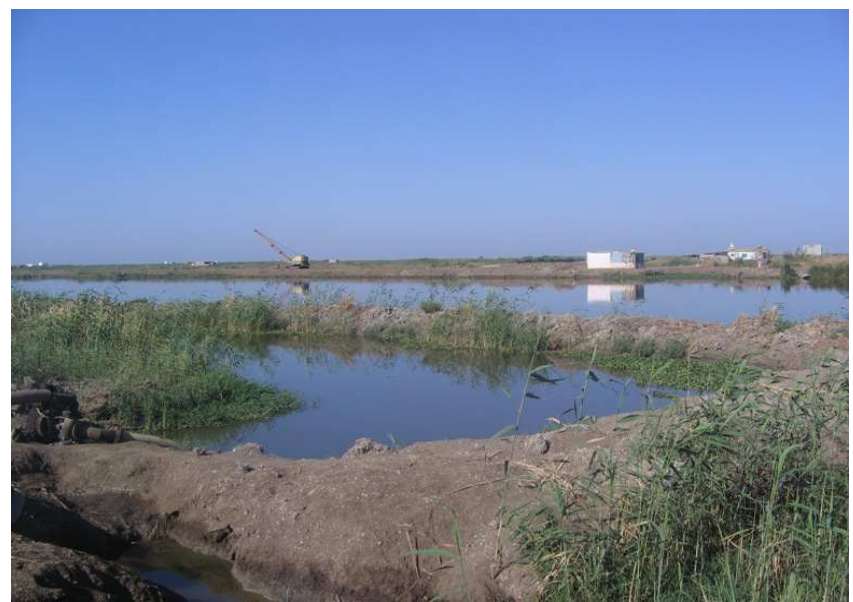

Photo 1. Fish farms adjacent to Bahr El-Baqar drain in Egypt (From Hamed et al. 2011).

Hamed 2008, studied the effect of fish farms on both of soil structure and soil salinity in area near the study area of the current research and with the same type of soil (heavy clay soil). He used blue dye (food-grade Vitasyn-Blau AE 90 from Swedish Hoechst Ltd) mixed with water in order to test the soil structure properties. He found that fish farming does not contribute to decrease in the soil salinity. He concluded that increasing fish farming activities may lead to increasing soil salinity problems in agricultural lands. The results showed also that there is no evidence that soil properties are enhanced by fish farming. On the contrary, the soil nutrient state appears to be decreasing. A layer of $10 \mathrm{~cm}$ thickness of mud layer with cracks is formed at the surface when the farm dried (Photo 2.).

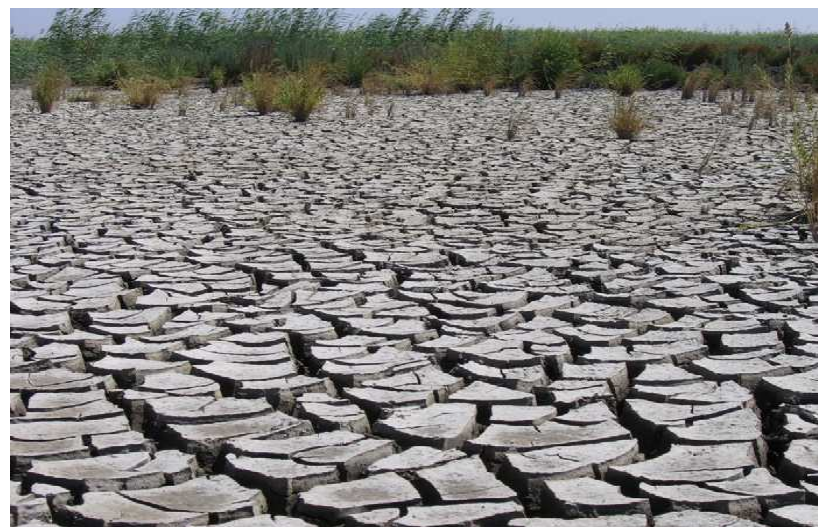

Photo 2. High amount of macropores and cracks at the mud layer accumulated at the surface In fish farm site (From Hamed 2008). 
Shang et al. (1998) concluded that extensive fish farming (shrimp) rapidly depleted the soil organic matter content. Other studies (Beverage \& Phillips, 1993; Deb, 1998; Flaherty et al., 1999) have reported that intensive and semi-intensive fish farming result in high volume of organic and inorganic effluents and toxic chemicals to the ecosystem that gives hypernutrification, eutrophication, and high soil toxicity. In Bangladesh, studies have shown that fish farming destroys the mangrove forest, increases soil acidity, salinity (farmers use sea water), and water pollution (Deb, 1998; Guimaraes, 1989; Hossain et al., 2004 Rahman, 1994). Ali (2006) examined the impact of shrimp farming on rice ecosystem in a village in southwestern Bangladesh. He reported that prolonged shrimp farming using sea water for a 5-, 10-, and 15-year period increased soil salinity, acidity, and significantly degraded the area's soil quality. It also drastically reduced the rice production and destroyed the aquatic and non-aquatic habitat inherent in the rice ecosystem.

A national project called El Salam Canal has recently finished. It relies on mixing water from the Damietta Branch of the Nile River with water from two major agricultural drains to be used for irrigation of 600,000 Feddan in the western side of Suez Canal and North Sinai. A total annual water requirement of 4.45 billion $\mathrm{m}^{3}$ of mixed water is required to irrigate 600,000 Feddan as follows:

- 2.11 billionm3 fresh water from the Damietta branch,

- 0.435 billionm3 drainage water from the Elserw drain, and

- 1.905 billionm3 drainage water from the Bahr Hadous drain.

The 200000 Feddan located within the service area of El Salam Canal in western part of Suez Canal spill their drainage water into Bahr El Baqar drain. Some agricultural areas located near the drain use El-Salam Canal water for irrigation. Due to the lack of the canal water, fish farms in the area forced to use other source of water. Unfortunately, the most easier source is the polluted Bahr El-Baqar drain.

The objective of this chapter is to conduct an integrated environmental assessment for fish farms located adjacent to the most polluted drain in northeastern Egypt and use its water for raising fish. A comparison between the pollution level in new/old fish farms using polluted water and agricultural lands use the same kind of waters will be conducted. The comparison will include also agricultural lands using fresh water from El-Salam Canal, lands subjected to fill from the drain and moor lands which play a reference role. An investigation of the available clues of the problem include using another drain to decrease pollution will be conducted. The level of pollution in soil and water will be recorded as a result of using the polluted water from the drain for irrigation and raising fish. The problem of seepage from the drain to the adjacent fish farms or from fish farms to the adjacent lands will be investigated. In order to achieve that water and soil samples have been collected and analyzed in order to calculate the concentrations of five main heavy metals $(\mathrm{Pb}, \mathrm{Zn}, \mathrm{Cd}, \mathrm{Cu}$ and $\mathrm{Mn})$. Samples were collected from different depths ranging from $1 \mathrm{~m}$ to $4 \mathrm{~m}$ in 24 different locations for the study area. In order to conduct a complete integrated environmental assessment to the problem, different locations have been chosen in new/old fish farms, moor lands, fill lands and agricultural lands using polluted drain water and fresh water from the canal.

\section{Locations of samples collected}

The field experiments were conducted by Salem et al 2011 in year 2009 in area located at the last $20 \mathrm{~km}$ of the Bahr El Baqar drain before it spills its water in Manzala Lake. The study area consists of fish farms, agricultural lands, lands subjected to fill from the drain and moor 
lands. The area is located within the service area of the national project El Salam Canal south of Port Said city.

Total of 24 boreholes were dug in 8 horizontal sections for different locations at the study area. Every horizontal section has length of 120-160 m from the Bahr El Baqar drain side and contains three boreholes. Fig 1, shows the location of the horizontal sections while Fig 2. shows the locations of the boreholes.

Four sections were taken at each side of the drain. The depth of each borehole is $2-4 \mathrm{~m}$. Five of boreholes were conducted in new/old fish farms. Three boreholes were conducted near the old fish farms (near the border of the farms). Six boreholes were conducted in moor lands and seven boreholes in fill land adjacent to the drain. Three boreholes were conducted in agricultural lands; two of them in agricultural land using the polluted water and one in agricultural land using fresh canal water. The agricultural land using fresh canal water has used polluted water from the drain for irrigation for 20 years and changed to use fresh water from the canal 5 years ago. The soil type in the study area is heavy clayey soil with more than $60 \%$ clay. Boreholes taken in moor lands will be used for comparison.

\section{Soil/water samples}

Two soil samples were collected from each borehole. Chemical analyses were carried out within $24 \mathrm{hr}$ of sampling at the laboratory. The concentrations of six heavy metals $(\mathrm{Pb}, \mathrm{Zn}$, $\mathrm{Cu}, \mathrm{Mg}$, and $\mathrm{Cd}$ ) were analyzed for each soil sample. Heavy metals were analyzed by the total adsorbed metals method according to USEPA (1986) using atomic spectrophotometer (model PYE UNICAM SP9, England).

The fish farms and the agricultural lands in the area are supposed to use fresh water from El-Salam canal or its branches but due to water shortage especially in summer most of the lands use the drain water for irrigation or for raising fish. There is a branch drain called Sarhan drain parallel to Bahr El Baqar drain at the eastern side located $100 \mathrm{~m}$ far from the drain. It collects the drainage water from the area nearby and spills it again to Bahr El-Baqar drain.

Boreholes were taken by rotary boring method at 8 sections, 4 sections at each side of Bahr El Baqar drain. Every section contains three bore holes. Two soil samples were taken from every borehole. One soil samples was taken above water table and the other taken under water table. The total depth of each borehole is 2-4 $\mathrm{m}$.

Table 1. shows locations and depths of boreholes. It shows also the type of land use of each borehole.

\subsection{Results of water samples from the drain}

Table (2) shows the concentrations of heavy metals for water samples taken from Bahr El Baqar drain at the same study area one year before the study was conducted (Hamed et al 2011). The results reflect the size of pollution of the drain water along the whole year.

\subsection{Comparison due to land use}

The objective of this section is to compare between new/old fish farms using polluted water and different land uses with different water quality used. The comparison will be between old fish farms, new fish farms, lands adjacent to old fish farms, agricultural lands use polluted water from the drain and agricultural lands use fresh water from Elsalam canal and fill resulted from the excavation of the drain sides and bottom and finally natural lands (moor). 


\begin{tabular}{|c|c|c|c|c|c|c|c|}
\hline Sector & Side & $\begin{array}{l}\text { Pore } \\
\text { hole }\end{array}$ & $\begin{array}{c}\text { Distance } \\
\text { From Bahr } \\
\text { El-Baqar } \\
\text { drain(m) }\end{array}$ & $\begin{array}{c}\text { Symbol / } \\
\text { no. }\end{array}$ & $\begin{array}{l}\text { Depth } \\
(\mathrm{m})\end{array}$ & using & $\begin{array}{l}\text { Water } \\
\text { table } \\
\text { depth }\end{array}$ \\
\hline \multirow{6}{*}{ S1 } & \multirow{6}{*}{ right } & \multirow{2}{*}{ S1b1 } & \multirow{2}{*}{60} & S1b1U & 1.5 & \multirow{2}{*}{$\begin{array}{c}\text { Old Fish } \\
\text { farm(10 years } \\
\text { old })\end{array}$} & \multirow{2}{*}{1.65} \\
\hline & & & & S1b1L & 4 & & \\
\hline & & \multirow{2}{*}{ S1b2 } & \multirow{2}{*}{142} & S1b2U & 1 & \multirow{2}{*}{$\begin{array}{c}\text { land adjacent to } \\
\text { old fish farm }\end{array}$} & \multirow{2}{*}{1.2} \\
\hline & & & & S1b2L & 3 & & \\
\hline & & \multirow{2}{*}{ S1b3 } & \multirow{2}{*}{162} & S1b3U & 1 & \multirow{2}{*}{$\begin{array}{c}\text { New Fish } \\
\text { farm(two years } \\
\text { old })\end{array}$} & \multirow{2}{*}{1.3} \\
\hline & & & & S1b3dL & 4 & & \\
\hline \multirow{6}{*}{ S2 } & \multirow{6}{*}{ right } & \multirow{2}{*}{$\mathrm{S} 2 \mathrm{~b} 1$} & \multirow{2}{*}{32.5} & S2b1U & 0.8 & \multirow{2}{*}{$\begin{array}{c}\text { Old Fish } \\
\text { farm(10 years } \\
\text { old })\end{array}$} & \multirow{2}{*}{2.2} \\
\hline & & & & S2b2L & 2.5 & & \\
\hline & & \multirow[b]{2}{*}{$\mathrm{S} 2 \mathrm{~b} 2$} & \multirow[b]{2}{*}{65} & S2b2U & 0.7 & \multirow{2}{*}{$\begin{array}{c}\text { Old Fish } \\
\text { farm(10 years } \\
\text { old })\end{array}$} & \multirow[b]{2}{*}{2.5} \\
\hline & & & & $\mathrm{S} 2 \mathrm{~b} 2 \mathrm{~L}$ & 2.75 & & \\
\hline & & \multirow{2}{*}{ S2b3 } & \multirow{2}{*}{131} & S2b3U & 0.7 & \multirow{2}{*}{$\begin{array}{c}\text { Fill from Sarhan } \\
\text { drain( } 5 \text { years } \\
\text { old })\end{array}$} & \multirow{2}{*}{1.5} \\
\hline & & & & S2b3L & 2 & & \\
\hline \multirow{6}{*}{ S3 } & \multirow{6}{*}{ left } & \multirow[b]{2}{*}{ S3b1 } & \multirow[b]{2}{*}{10} & S3b1U & 0.5 & \multirow{2}{*}{$\begin{array}{l}\text { Fill from Bahr } \\
\text { El-Baqar drain } \\
(15 \text { years old })\end{array}$} & \\
\hline & & & & S3b2L & 2 & & 0.7 \\
\hline & & $\mathrm{s} 3 \mathrm{~b} 2$ & 27 & S3b2U & 0.5 & & 085 \\
\hline & & 5002 & 27 & S32b2L & 1.5 & moor & 0.00 \\
\hline & & 8010 & 4 & S3b3U & 0.5 & & 1 \\
\hline & & SUDS & 44 & S3b3L & 1.5 & moor & 1 \\
\hline & & & & S4b1U & 0.5 & Fill from Sarhan & \\
\hline & & $54 \mathrm{~b} 1$ & 35 & S4b1L & 3 & $\begin{array}{c}\text { drain (5 years } \\
\text { ago) }\end{array}$ & 1 \\
\hline & & C & & S4b2U & 1 & & \\
\hline 4 & II"पा & $5+02$ & 70 & S4b2L & 3.5 & moor & 1 \\
\hline & & & & S4b3U & 1.5 & Cultivated land & \\
\hline & & S4b3 & 106.5 & S4b3L & 3.5 & $\begin{array}{l}\text { using El-salam } \\
\text { canal water }\end{array}$ & 2.3 \\
\hline
\end{tabular}




\begin{tabular}{|c|c|c|c|c|c|c|c|}
\hline \multirow{5}{*}{ S5 } & \multirow{5}{*}{ left } & S5b1 & 35 & $\begin{array}{l}\text { S5b1U } \\
\text { S5b2L }\end{array}$ & 4 & $\begin{array}{l}\text { Cultivated lands } \\
\text { using Bahr El- } \\
\text { Baqar drain } \\
\text { water }\end{array}$ & 3.5 \\
\hline & & \multirow{2}{*}{ S5b2 } & \multirow{2}{*}{72} & S5b2U & 1 & \multirow{2}{*}{$\begin{array}{l}\text { land adjacent to } \\
\text { old fish farm }\end{array}$} & \multirow{2}{*}{2.3} \\
\hline & & & & S5b2L & 3 & & \\
\hline & & \multirow{2}{*}{ S5b3 } & \multirow{2}{*}{120} & S5b3U & 0.5 & \multirow{2}{*}{$\begin{array}{c}\text { New Fish } \\
\text { farm(two years } \\
\text { old ) }\end{array}$} & \multirow{2}{*}{0.7} \\
\hline & & & & S5b3L & 3 & & \\
\hline \multirow{6}{*}{ S6 } & \multirow{6}{*}{ right } & \multirow{2}{*}{ S6b1 } & \multirow{2}{*}{35} & S6b1U & 0.5 & \multirow{2}{*}{$\begin{array}{l}\text { Fill from Bahr } \\
\text { El-Baqar drain } \\
\text { (20 years old) }\end{array}$} & \multirow{2}{*}{0.7} \\
\hline & & & & S6b2L & 2 & & \\
\hline & & \multirow{2}{*}{ S6b2 } & \multirow{2}{*}{67} & S6b2U & 0.5 & & \multirow{2}{*}{3.6} \\
\hline & & & & S6b2L & 3.75 & moor & \\
\hline & & \multirow[b]{2}{*}{ S6b3 } & \multirow[b]{2}{*}{114} & S6b3U & 0.5 & \multirow{2}{*}{$\begin{array}{l}\text { Cultivated land } \\
\text { using Bahr El- } \\
\text { Baqar drain }\end{array}$} & \multirow[b]{2}{*}{1.75} \\
\hline & & & & S6b3L & 2.5 & & \\
\hline \multirow{6}{*}{ S7 } & \multirow{6}{*}{ left } & \multirow{2}{*}{ S7b1 } & \multirow{2}{*}{35} & S7b1U & 1 & & \multirow{2}{*}{1} \\
\hline & & & & S7b1L & 3 & moor & \\
\hline & & \multirow{2}{*}{ S7b2 } & \multirow{2}{*}{63} & S7b2U & 0.8 & & \\
\hline & & & & S7b2L & 2 & moor & 1 \\
\hline & & $57 \mathrm{~h} 2$ & 72 & S7b3U & 0.5 & land adiacent to & 7 \\
\hline & & S/b3 & 73 & S7b3L & 2 & old fish farm & 0.7 \\
\hline & & & & S8b1U & 1 & Fill from Bahr & \\
\hline & & S8b1 & 40 & S8b1L & 2.75 & $\begin{array}{l}\text { El-Baqar drain } \\
\text { (15 years old) }\end{array}$ & 2.25 \\
\hline & & & & S8b2U & 1 & Fill from Bahr & \\
\hline S8 & left & S8b2 & 80 & S8b2L & 3 & $\begin{array}{l}\text { El-Baqar drain } \\
\text { (15 years old) }\end{array}$ & 2.75 \\
\hline & & & & S8b3U & 1 & Fill from Bahr & \\
\hline & & S8b3 & 115 & S8b3L & 2.2 & $\begin{array}{l}\text { El-Baqar drain } \\
(20 \text { years old })\end{array}$ & 1.9 \\
\hline
\end{tabular}

Table 1. Locations and depths of boreholes and type of land uses (U: upper layer. L: lower layer) (From Salem et al. 2011). 


\begin{tabular}{|c|c|c|c|c|c|c|c|c|c|c|c|c|c|}
\hline \multirow{3}{*}{$\stackrel{\stackrel{D}{*}}{\omega}$} & \multicolumn{13}{|c|}{ Concentration in $\mathrm{mg} /$ liter } \\
\hline & \multicolumn{4}{|c|}{ Year 2008} & \multicolumn{9}{|c|}{ Year 2009} \\
\hline & Sep. & Oct. & Nov. & Dec. & Jan. & Feb. & Mar. & Apr. & Jul. & Aug. & Sep. & Oct. & Nov. \\
\hline $\mathrm{Cu}$ & 0.151 & 0.022 & 0.204 & 0.245 & 0.062 & 0.005 & 0.045 & 0.106 & 0.083 & 0.014 & 0.012 & 0.008 & 0.011 \\
\hline $\mathrm{Pb}$ & 0.749 & 0.235 & 0.273 & 0.195 & 0.088 & 0.030 & 0.287 & 0.041 & 0.033 & 0.053 & 0.009 & 0.031 & 0.066 \\
\hline $\mathrm{Zn}$ & 0.139 & 0.549 & 2.066 & 1.438 & 0.431 & 0.333 & 0.688 & 0.031 & 0.095 & 0.199 & 0.024 & 0.028 & 0.051 \\
\hline $\mathrm{Cd}$ & 0.069 & 0.061 & 0.017 & 0.062 & 0.101 & 0.199 & 0.032 & 0.128 & 0.001 & 0.025 & 0.021 & 0.016 & 0.016 \\
\hline $\mathrm{Mn}$ & 2.573 & 3.935 & 0.084 & 0.065 & 0.281 & 0.56 & 0.278 & 0.519 & 0.064 & 0.010 & 0.011 & 0.125 & 0.816 \\
\hline
\end{tabular}

Table 2. The values of heavy metals in drain water for one year (From Hamed et al. 2011).

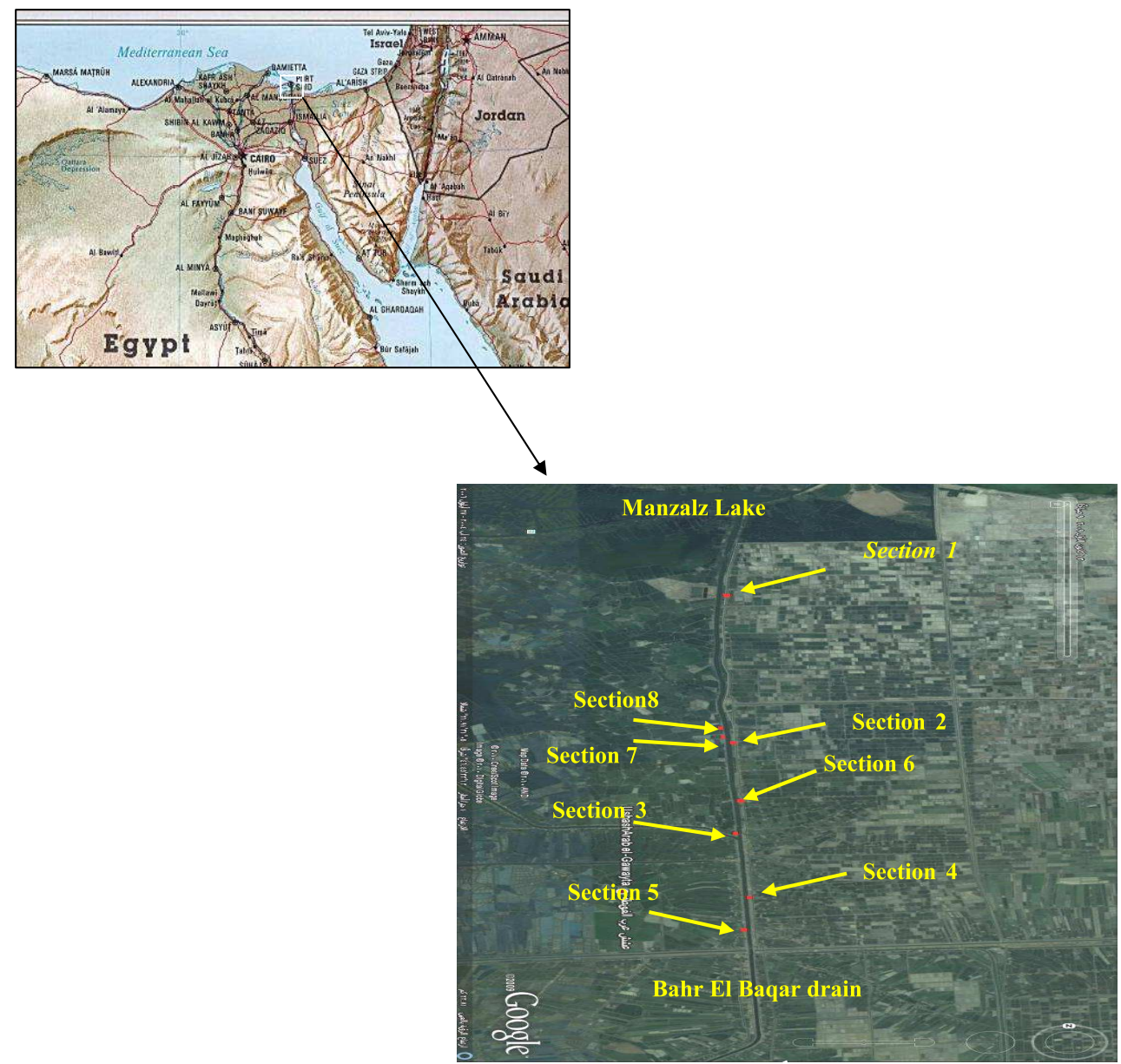

Fig. 1. Locations of the study area (From Salem et al. 2011). 


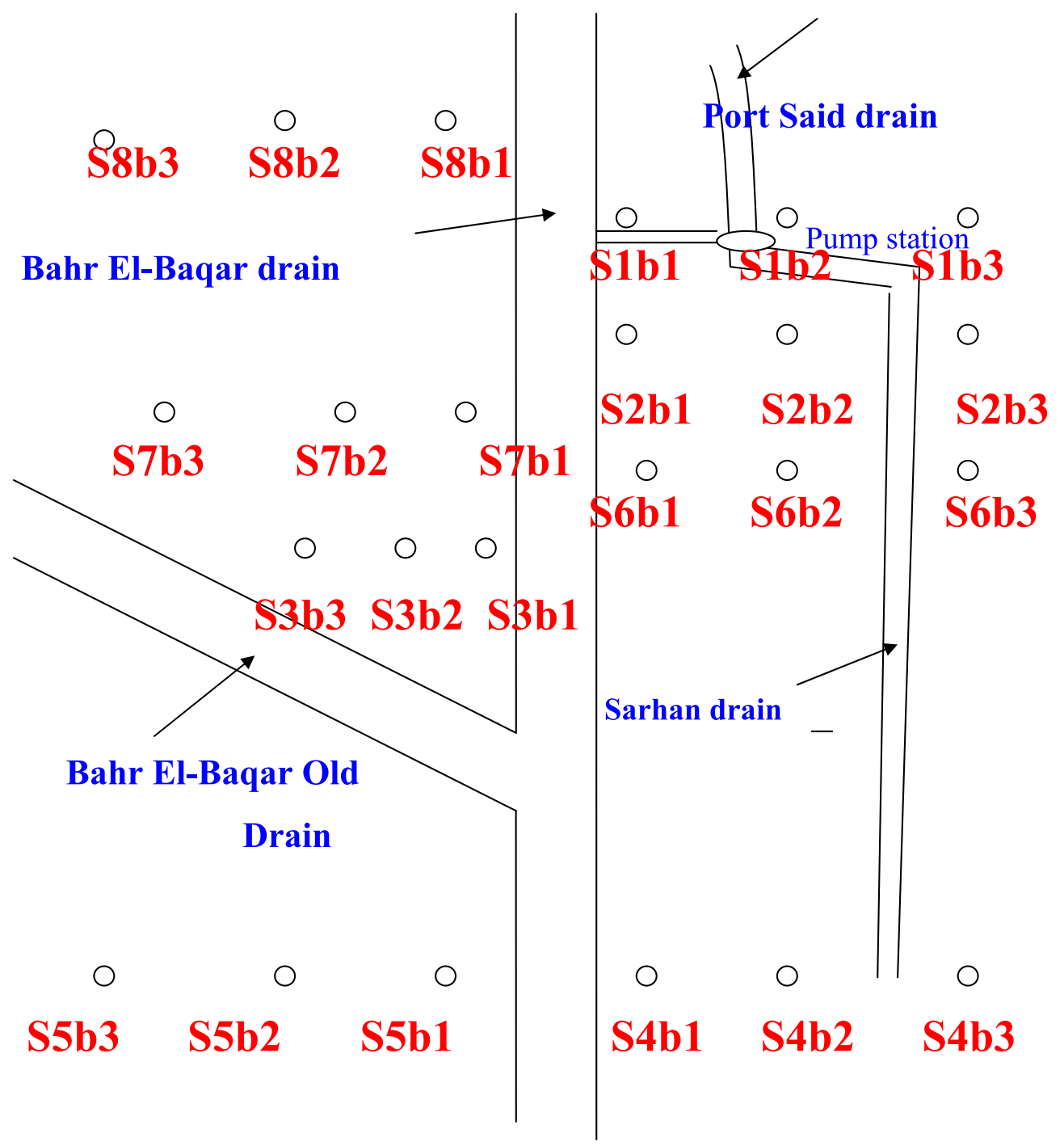

Fig. 2. Layout of the boreholes (From Salem et al. 2011).

Fig (3) shows the difference between the concentrations of heavy metals in samples of top soil as a result of different land uses. The results showed that the old fish farms that used Bahr El-Baqar drain water have the highest percentage of heavy metals. And the second highest rate exists in the agricultural land irrigated with polluted water from Bahr El-Baqar drain for along time. And the third highest concentration of heavy metals is in the land adjacent to the fish farm that uses Bahr El-Baqar drain water. It indicates that the fish farms using polluted water significantly affect the neighboring land. 
Next is land exposed to fill which exists only in top soil. In this case the concentration of heavy metals depends mainly on the age of the fill and its original location. There are two types of fill, fill comes from polluted Bahr-ElBaqar drain and fill comes from the agricultural minor drain (Sarhan drain). For fill from Bahr El-Baqar drain, the concentration is decreased with the increase of the fill age. The lowest concentration is for the fill has age of 20-25 years. It could be attributed to the increase in pollution of the drain bottom soil by time. The reason could be the increase in population and the increase in industry spread in the recent decades which cause increase in untreated waste water and industrial disposal spilled into the drain. In spit of the new fill comes from the relatively less polluted drain, Sarhan drain, it has a high concentration ratio of heavy metals. It is known that Sarhan drain receives drainage water from fish farms and agricultural lands using polluted water from Bahr El Baqar drain for irrigation and raising fish.

Next are the new fish farms that used Bahr El-Baqar drain water, and finally, the lowest heavy metal concentrations were found in both of the agricultural land uses fresh water from ElSalam Canal and the natural lands (moor lands).

Fig (4) shows the difference between the concentrations of heavy metals in samples of lower soil as a result of different land uses. Nearly the same results as in top soil were obtained except for that the land adjacent to the fish farms which used Bahr El-Baqar drain water has the highest percentage of heavy metals. This is a good proof that the fish farms using polluted water significantly affect the neighboring land especially in lower soil layers. The old fish farms that used Bahr El-Baqar drain water receive the second highest rate in the concentrations of heavy metal. And the third highest concentration of heavy metals is the agricultural land irrigated with water from Bahr El-Baqar drain for along time, Next is the new fish farms that used Bahr El-Baqar drain water, and the finally is the moor lands.

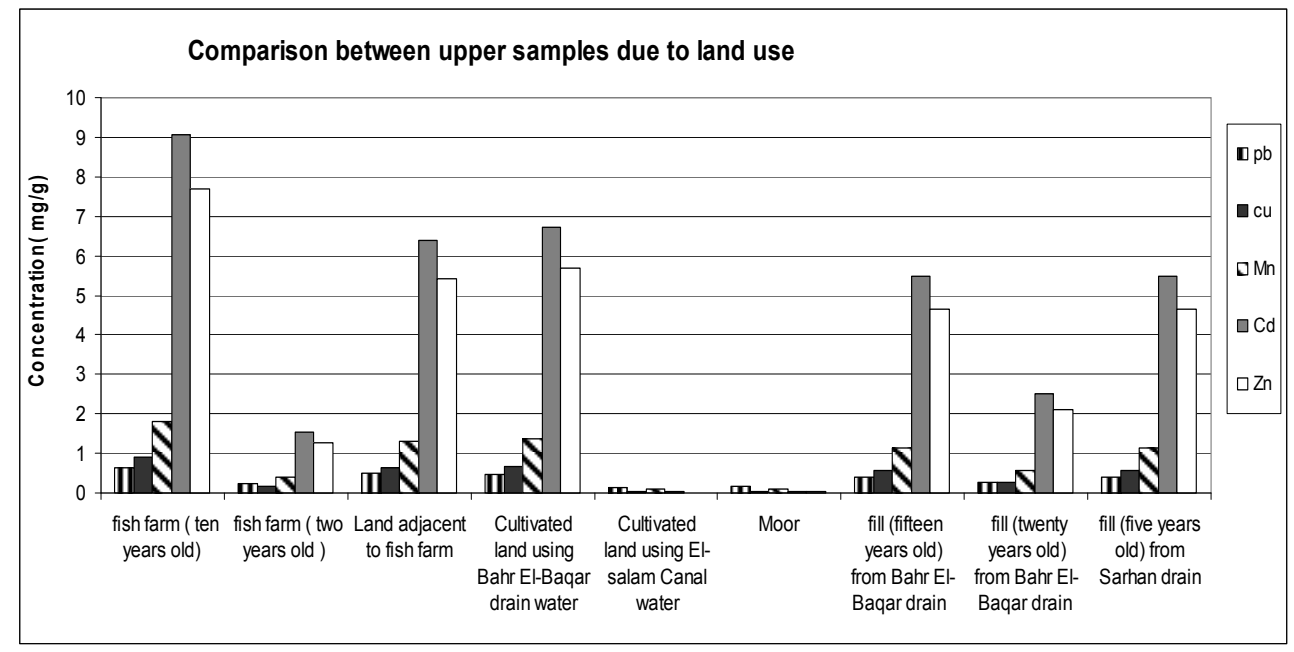

Fig. 3. Mean heavy metals concentrations in upper soil samples for different land uses, mg/liter (From Salem et al. 2011). 


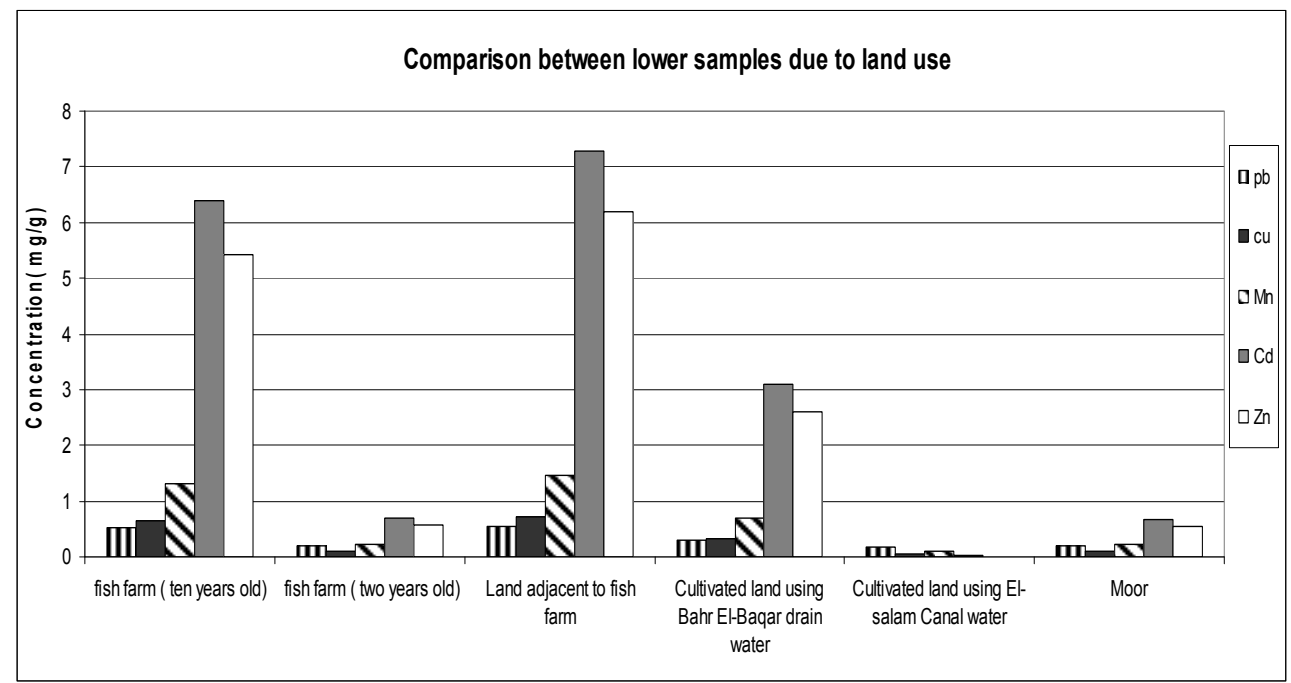

Fig. 4. Mean heavy metals concentrations in lower soil samples for different land uses, $\mathrm{mg} /$ liter (From Salem et al. 2011).

\subsection{Comparison due to location from Bahr El-Baqar drain}

In the current section, comparison of new/old fish farms and other land uses will be investigated in details for each section and each borehole. Moreover, effect of seepage from the polluted drain or from fish farms to the adjacent lands will be studied. Boreholes were dug in different distances and locations in lands with different land uses. The distances from the drain were kept nearly constants for different sections. Here, the effect of minor drain (Sarhan drain) parallel to Bahr El-Baqar drain and at $100 \mathrm{~m}$ far will be investigated. There is a question needs to be answered, will the minor drain work as a defend barrier for seepage from the polluted drain to the lands located on the minor drain side? Will it affect the fish farms using polluted water? For the coming section, only the data for the lower soil layer will be used in order to investigate the seepage from the drain and fish farms.

Fig (5) shows heavy metals concentrations of boreholes in section (1). It shows concentrations in boreholes S1b1, S1b2 and S1b3 located in old fish farms, land adjacent to old fish farms and new fish farms respectively. It is clear from the figure that the seepage factor from the main drain is not dominated here. The highest heavy metal concentrations are found in bore hole S1b2 (land adjacent to old fish farm) not in S1b1 the closest borehole to the main drain. The effect of the minor drain (Sarhan drain) is not clear here since borehole S1b2 has a high ratio of heavy metals concentration. It is probably due to the influence of pump station near the section. It seems that the type of land use is the dominated factor for the pollution concentration in this section.

Fig (6) shows mean heavy metals concentrations of boreholes in section (2). It shows concentrations in boreholes S2b1, S2b2 and S2b3 located in old fish farms for the first two boreholes and fill from Sarhan drain for the third one. The highest heavy metal concentrations are found in borehole S2b2. Also, in this section it is clear that the seepage factor from the main drain is not dominated. The values of concentrations in old fish farm (10 years old) $65 \mathrm{~m}$ far from the drain are higher than that the corresponding values in old 
fish farms $32.5 \mathrm{~m}$ away. The pollution in fill from Sarhan drain (5 years old) is lesser than that in old fish farms. It is probably due to the high pollution accumulation in old fish farms and the fill location near Sarhan drain.

Fig (7) shows heavy metals concentrations in section (3). It shows concentrations in boreholes S3b1, S3b2 and S3b3 located in fill from Bahr El Baqar drain for the first borehole and moor land for the second and the third ones. The dominated factor here is the land use factor. The higher value of concentration exists in second borehole. The ratio of concentration in this section is small compared with other sections. It is probably due to moor lands (natural land) which contain less amount of pollution and the low effect of drain seepage. In fill borehole, the effect of fill is small since the soil sample was taken in $2 \mathrm{~m}$ depth.

Fig (8) shows heavy metals concentrations in section (4). It shows concentrations in boreholes S4b1, S4b2 and S4b3 located in fill from Sarhan drain (5 years ago), moor land and agricultural lands using water from ElSalam canal respectively. The ratio of concentration in this section is small compared with other sections. The seepage factor here also is not dominated. The less concentration is found in agricultural lands using water from ElSalam canal. The location of Sarhan drain adjacent to the agricultural lands could be another factor contributing for lower pollution concentration in its soil.

Fig (9) shows heavy metals concentrations in section (5). It shows concentrations in boreholes S5b1, S5b2 and S5b3 located in cultivated lands using Bahr El-baqar drain water, land adjacent to old fish farm and New Fish farm (two years old) respectively. The higher concentrations of heavy metals are located in both of cultivated land with Bahr El baqar water and land adjacent to fish farms. These results reflect the bad effect of using polluted water for irrigation and the effect of fish farms on the adjacent lands. The relatively less concentration is located in new fish farms. However, only two years of fish farming using polluted water has raised the pollution concentration many times (see Fig (3) moor land and new fish farms).

Fig (10) shows heavy metals concentrations in section (6). It shows concentrations in boreholes S6b1, S6b2 and S6b3 located in Fill from Bahr El-Baqar drain (20 years old), moor lands and cultivated land using Bahr El-Baqar drain respectively. Soil sample was taken at $2 \mathrm{~m}$ depth in fill borehole. Consequently, the effect of fill is small. The ratios of concentration in moor land are nearly the same as that for old fill from Bahr El Baqar drain. The unexpected results here are the lower ratio of concentration for cultivated land using Bahr El-Baqar drain although the soil sample was taken from the root zone area. It is probably due to the effect of Sarhan drain adjacent to the lands. However, the ratio of concentrations still relatively high compared with land using fresh water for irrigation. Again, seepage is not a dominated factor here.

Fig (11) shows heavy metals concentrations in section (7). It shows concentrations in boreholes S7b1, S7b2 and S7b3 located in moor lands for the first two boreholes and in land adjacent to old fish farms for the third one. The effect of old fish farm on the lands nearby is quit clear here. The difference in heavy metals concentrations between land adjacent to fish farms and moor land is quite high. It reflects the damage effect of fish farms not only on its own soil but also on the soil nearby. It is probably due to the high polluted water level in fish farms which infiltrate to the adjacent lower level lands.

Fig (12) shows heavy metals concentrations in section (8). It shows concentrations in boreholes S8b1, S8b2 and S8b3 located in fill from Bahr El-Baqar drain for 15, 15 and 20 years old respectively. Unlike other sections, seepage factor could be effective here. Another possible reason is the existence of some fill traces in deep layers. 


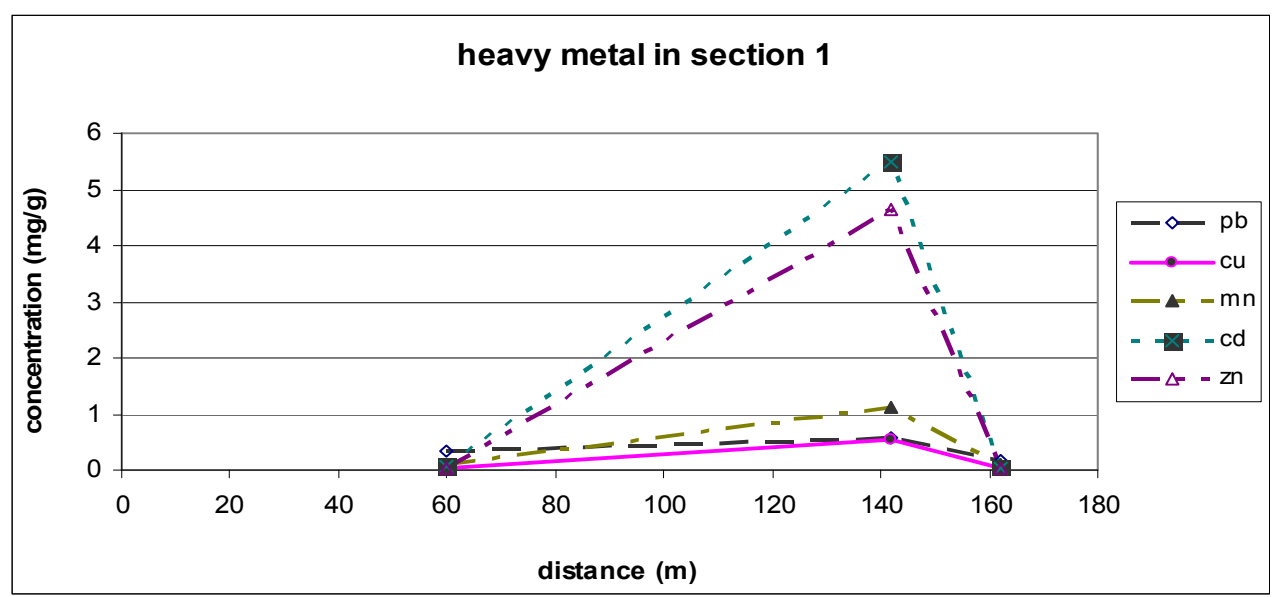

Fig. 5. Heavy metals concentrations in section (1), mg/liter (From Salem et al. 2011).

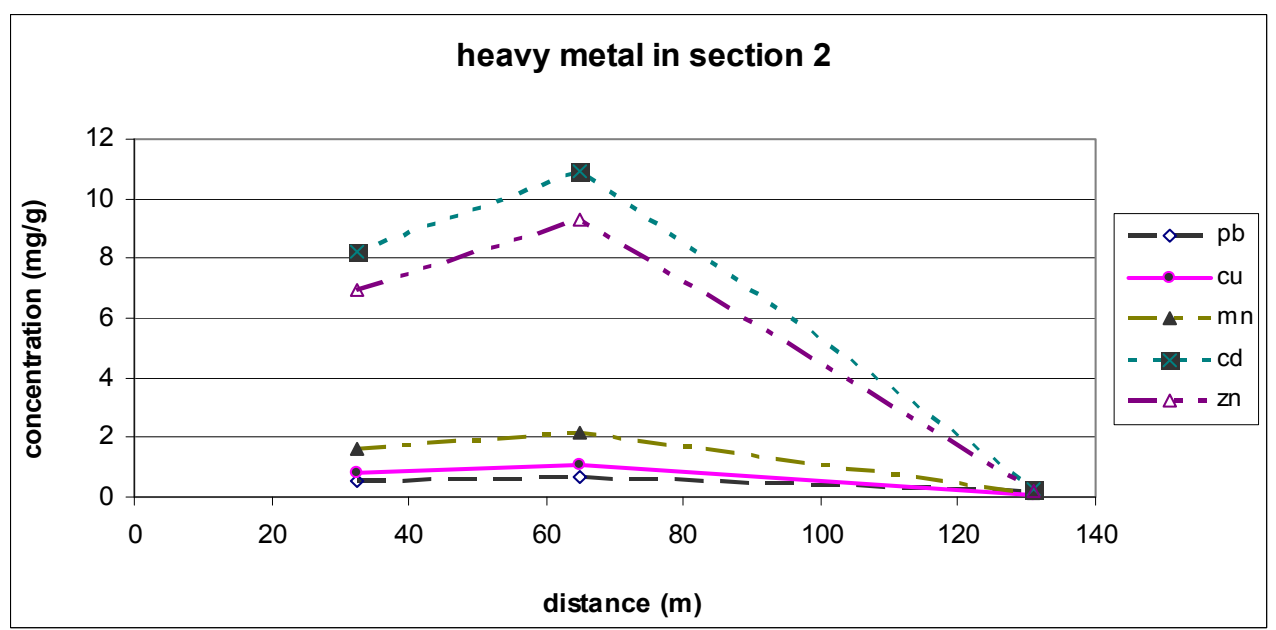

Fig. 6. Heavy metals concentrations in section (2), mg/liter (From Salem et al. 2011). 


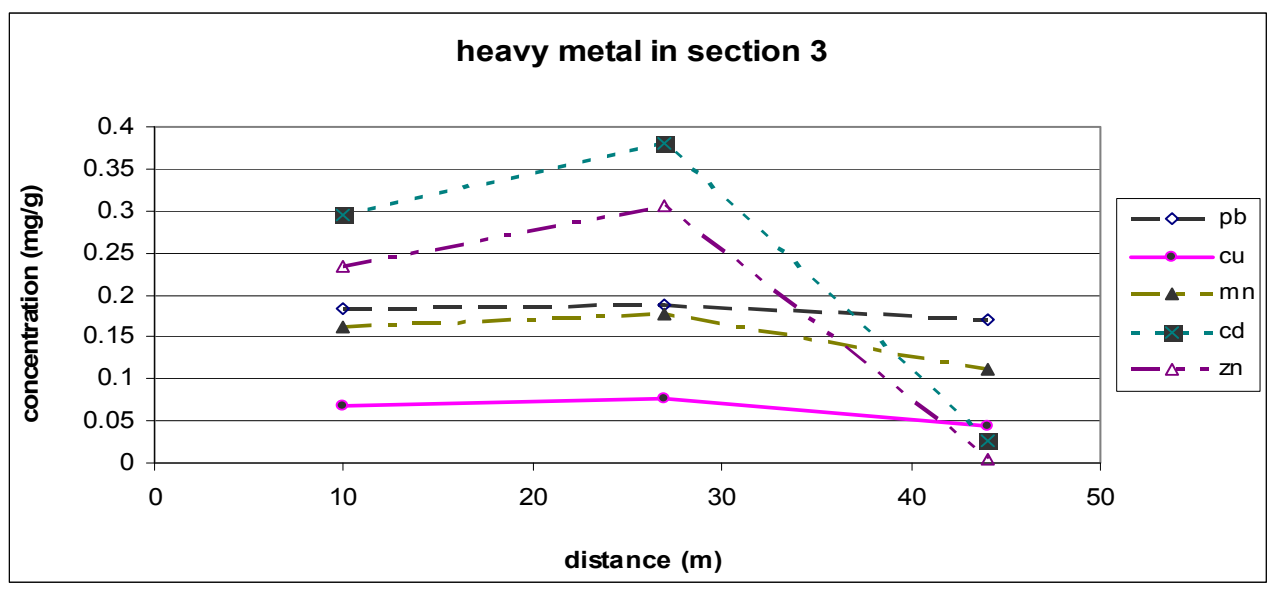

Fig. 7. Heavy metals concentrations in section (3), mg/liter (From Salem et al. 2011).

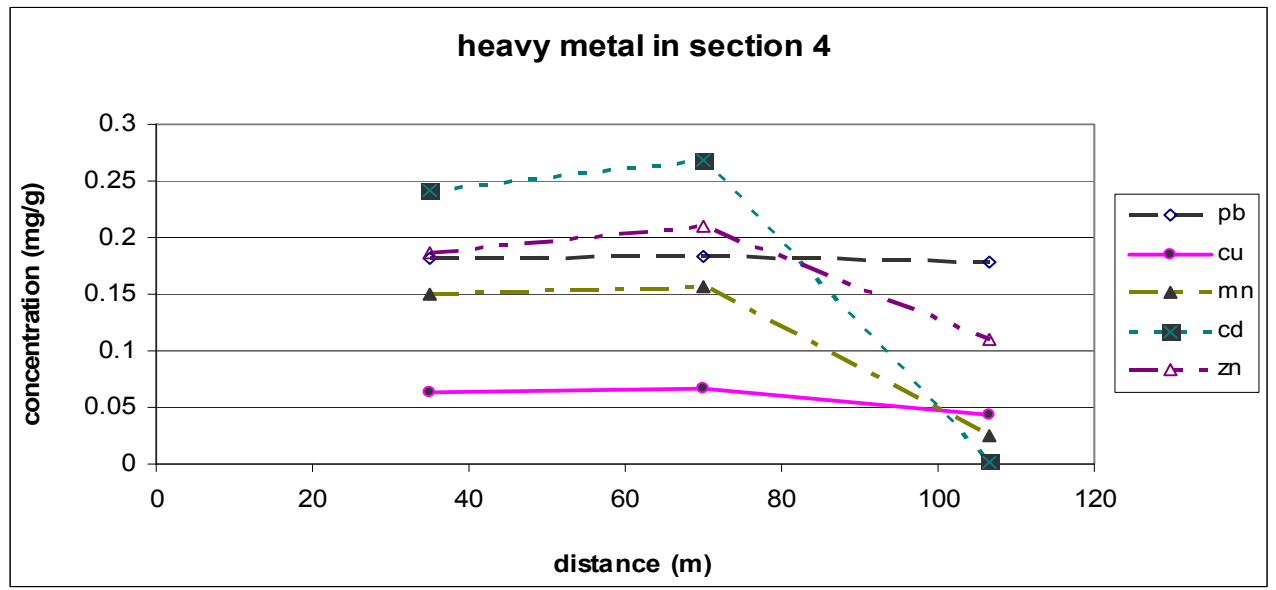

Fig. 8. Heavy metals concentrations in section (4), mg/liter (From Salem et al. 2011). 


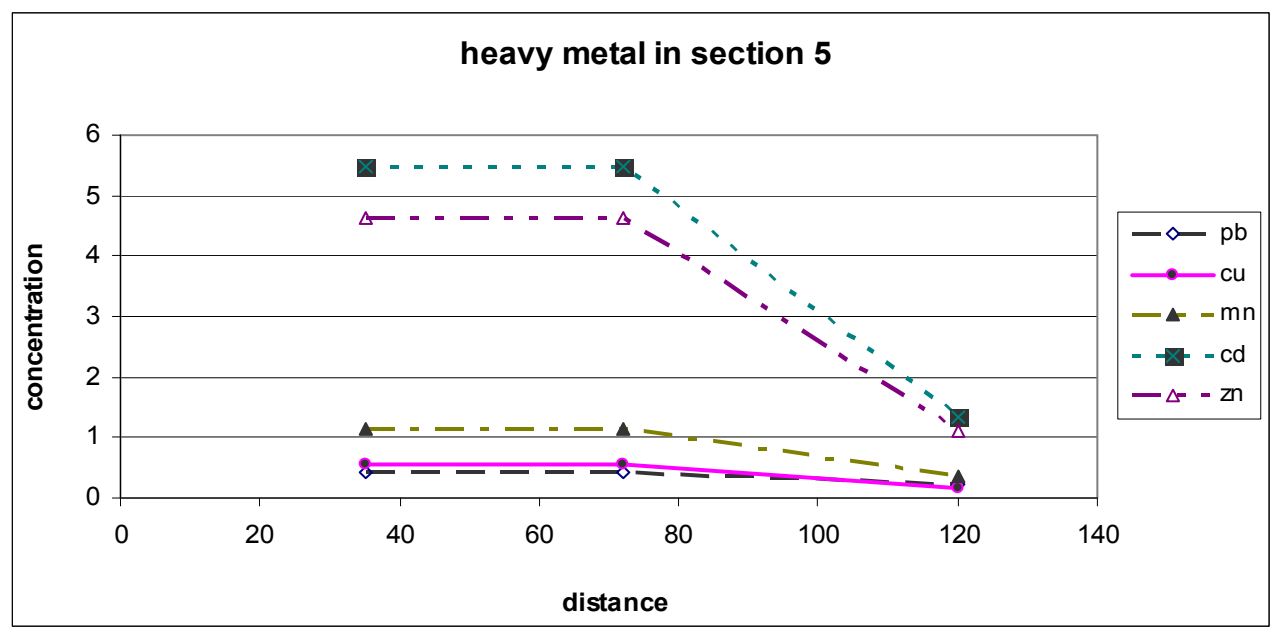

Fig. 9. Heavy metals concentrations in section (5), mg/liter (From Salem et al. 2011).

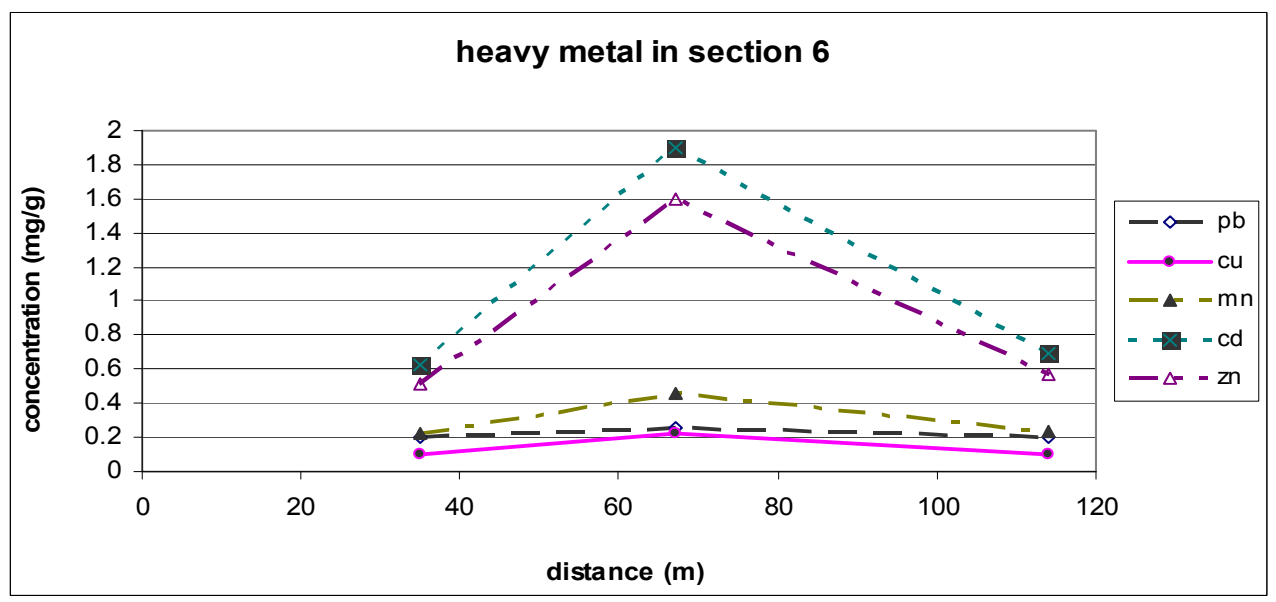

Fig. 10. Heavy metals concentrations in section (6), mg/liter (From Salem et al. 2011). 


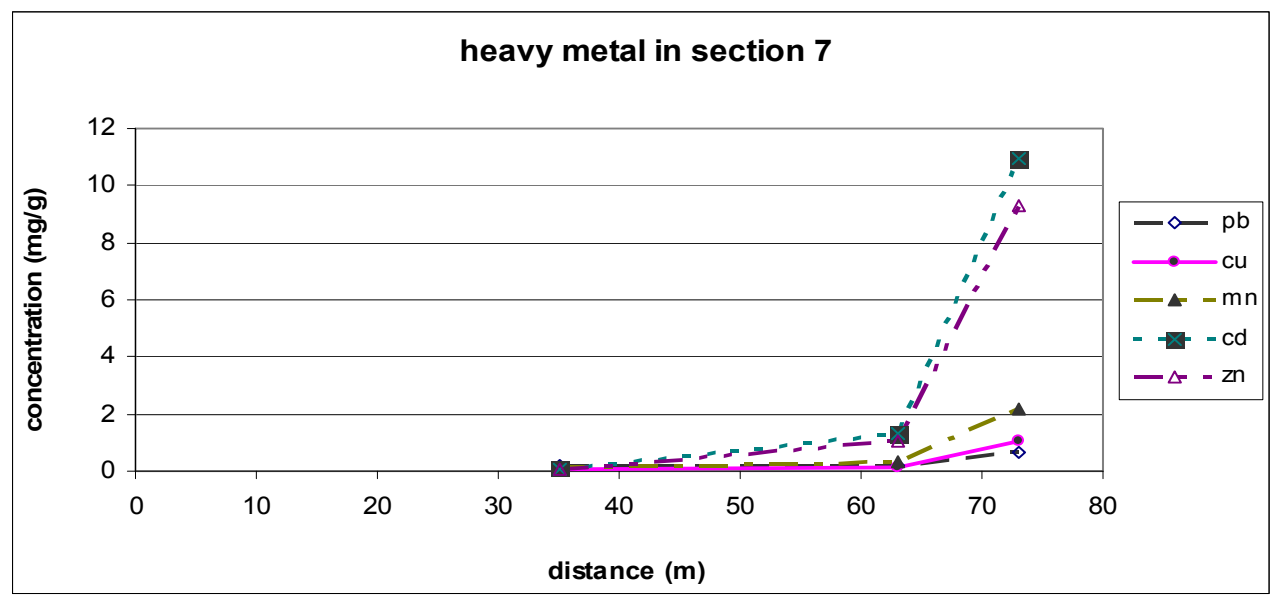

Fig. 11. Heavy metals concentrations in section (7), mg/liter (From Salem et al. 2011).

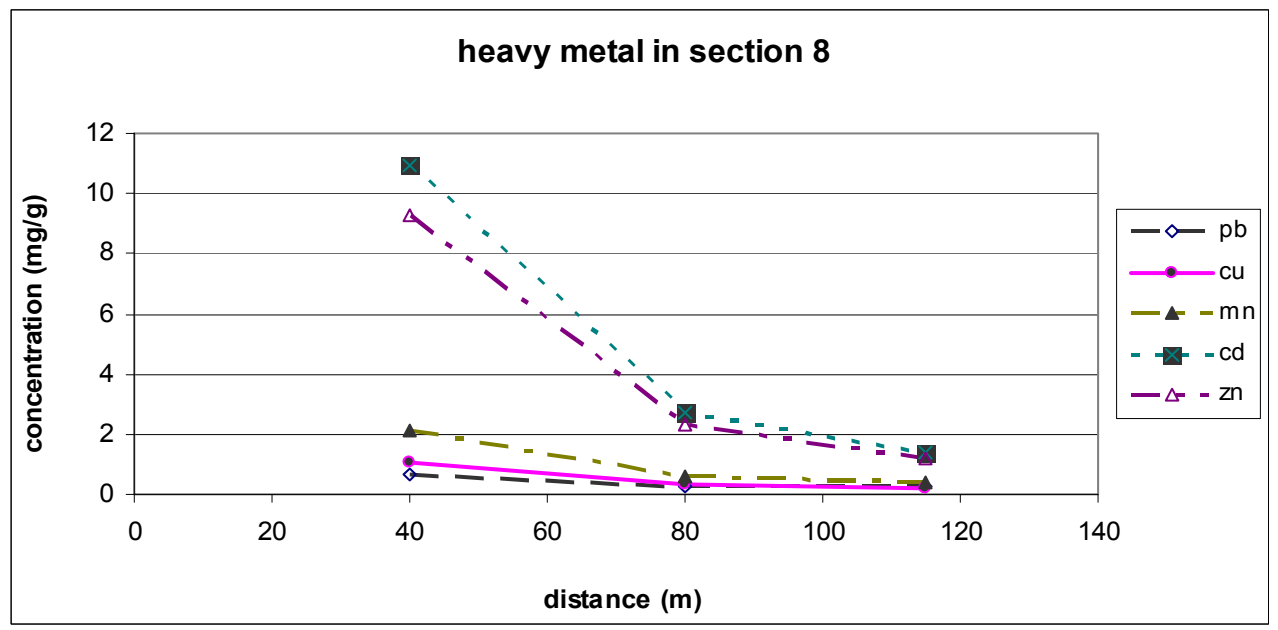

Fig. 12. Heavy metals concentrations in section (8), mg/liter (From Salem et al. 2011). 


\section{Summary and conclusions}

In this chapter, an integrated environmental assessment has been conducted for fish farms using polluted water in area located within the service area of the most polluted drain in Egypt (Bahr el Baqar drain). The chapter focuses on two previous studies (Salem et al. 2011), (Hamed, et al. 2011). Total of 24 boreholes in 8 different sections on both sides of the drain have been dug in order to collect soil samples for depths ranging from 1 to $4 \mathrm{~m}$. Samples were sent to the laboratory in order to measure the concentrations of five heavy metals $(\mathrm{Pb}$, $\mathrm{Zn}, \mathrm{Cd}, \mathrm{Cu}$ and $\mathrm{Mn}$ ). Boreholes were excavated in different land uses and in different spaces from the polluted drain in order to conduct an integrated comparison between fish farms using polluted water and other land uses.

Results showed that the most polluted areas are the old fish farms (10 years old) using polluted water from the drain for raising fish and the land adjacent to it. It reflects the harmful effect of using polluted water for long time for raising fish not only on farms soil itself but also on the soil adjacent to the fish farms. Consequently, the pollution will reach fish produced from these farms and transferred to human affecting their health. Moreover, even in new fish farms with only less than two years old, the increase in heavy metals concentrations in soil is quite high during short period of time.

The level of pollution in fish farms using polluted water is much more the level of pollution in agricultural lands using polluted water from the drain in irrigation. Both of fish farms and the agricultural lands have the same age in using polluted water from the drain. Also, the chapter warns about using polluted water for irrigation in agricultural lands. It proved the bad effect of such kind of water on soil and hence in plants since the digging depth is within the root zone (1-3).

This conclusion will stand against those people supporting the use of polluted drain water for irrigation or for raising fish.

Fill from both of Bahr ElBaqar drain and from agricultural drain (Sarhan drain) comes after as a third higher ratio of pollution. The quality of older fill from the polluted drain is better than the recent one. It is probably due to the increase in concentration of pollution by time in drain bottom soil. The difference in concentration is too high in a relatively short period of time. This reflects the rapid deterioration of the environmental situation for Bahr El Baqar drain by time. Since fish farms and agricultural lands using polluted water are using the minor drain (Sarhan drain) for drainage, the fill coming from this drain contains high ratio of heavy metals concentration. Unfortunately, many fish farms owners use such kind of fill for constructing banks around their farms. They use the fill also for increasing the level of their farms bed soil.

For agricultural lands which have used polluted water for irrigation for long time (20 years) and changed to use fresh water for relatively less period of time (5 years), the improvement of its soil quality is quite clear. The decrease in heavy metals due to use of good quality of water is rather high. It will give an optimistic view for obtaining a clue for pollution in the area. Furthermore, the existing of minor drain parallel to the major polluted drain in relatively small distance $(90-100 \mathrm{~m})$ contributes for reducing pollution for lands located after the minor drain in most cases. Consequently, as a current solution, the local government should force fish farms owners to use fresh water for washing their lands for long period of time before they use it again for fish farms.

The Chapter revealed that the overall environmental situation at the area on both sides of the drain is quite dangerous. Five dangerous heavy metals with different concentrations 
have been found in each soil sample on surface or deep on the ground. This pollution hazardous level has its bad effect on both of fauna and flora at the area.

Finally, the Chapter revealed that fish farming with polluted water has very bad consequences to the surrounding environment, not to mention to the fish itself. Moreover, previous studies have proved that the fish farming for long time with good quality water has a bad effect on the soil structure and soil salinity. Hence, we can imagine the level of environmental deterioration as a result of using polluted water in fish farming.

\section{Acknowledgments}

The field and publishing work was financially supported by the Swedish Research Council (SIDA) through a cooperation project between Suez Canal University, Port Said branch (Port Said University now) (Egypt) and Lund University (Sweden) under the title: "Sustainable use of Cairo waste water; environmental effects of the Bahr el Baqar Drain", in which Yasser Hamed is the principal investigator and Prof Atef Alam El-Din the University Vice President is the main supervisor.

\section{References}

Abdel-Azeem, A. M; Abdel-Moneim, T. S.; Ibrahim, M. E.; Hassan, M. A. A. \& Saleh, M. Y. (2007). Effects of Long-Term Heavy Metal Contamination on Diversity of Terricolous Fungi and Nematodes in Egypt - A Case Study. Water Air Soil Pollut. Journal, No. 186, pp.:233-254.

Abdel-Shafy, H. I., \& Aly, R. O. (2002). Water issue in Egypt: Resources, pollution and protection endeavors. CEJOEM, 8(1), 3-21.

Ali, A.M.S., 2006. Rice to shrimp: land use/land cover changes and soil degradation in Southwestern Bangladesh. Journal of Land Use Policy 23, 421-435.

Ali, O. M.; El-Sikhry, E. M., \& El-Farghal, W. M. (1993). Effect of prolonged use of Bahr El Baqar drain water for irrigation on the total heavy metals content of South Port Said soils. In: Proc. 1st Conf. Egypt. Hung. Env. Egypt, pp. 53-57.

Beverage, M. \& Phillips, M., (1993). Environmental impact of tropical inland aquaculture. In: Pullin, R., Rosenthal, H., Maclean, J. (Eds.), Environment and Aquaculture. Center for Tropical Aquaculture Research, Manila, pp. 213-236.

Deb, A.K., (1998). Fake blue revolution: environmental and socioeconomic impacts of shrimp culture in coastal Bangladesh. Ocean and Coastal Management 41, 63-88.

Ezzat, A. I. (1989). Studies on phytoplankton in some polluted areas of Lake Manzala. Bulletin of the National Institute of Oceanography and Fisheries, ARE, 15(1), 1-19.

Flaherty, M., Vandergeest, P. \& Miller, P., (1999). Rice paddy or shrimp pond: tough decisions in rural Thailand.World Development 27 (12), 2045-2060.

Guimaraes, J.P. de Compos, (1989). Shrimp culture and market incorporations: a study of shrimp culture in paddy fields in Southwest Bangladesh. Development and Change $20(4), 333$.

Hamed, Y. (2008). Soil structure and salinity effects of fish farming as compared to traditional farming in northeastern Egypt. Land Use Policy Journal 25(3) pp 301308, July 2008. 
Hamed, Y., Shawky, T., Abd-Elrehim, M., ElKiki, M., Berndtsson, R. \& Persson,K.,(2011) Case Study: Investigation of different potential causes of pollution in Lake Manzala northeastern of Egypt. Article in Press.

Hossain, S., Alam, S.M.N., Lin, C.K., Demaine, H., Khan, Y.S.A., Das, N.G. \& Roup, M.A., (2004). Integrated management approach of shrimp culture development in the coastal environment of Bangladesh. World aquaculture development in the coastal environment of Bangladesh. World Aquaculture 35 (4), 35-44.

Khalil, M. T. (1985). The effect of sewage and pollutional wastes upon Bahr El-Baqar Drain and the southern area of Lake Manzala, Egypt. Egyptian Journal of Wildlife and Natural Resources, 6, 162-171.

Rahman, A., 1994. The impact of chrimp culture on the coastal environment. In: Rahman, A.A., Haider, R., Huq, S., Jansen, E.G. (Eds.), Environment and Development in Bangladesh. University Press Ltd., Dhaka, pp. 490-524.

Rashed, I. G., \& Holmes, P. G. (1984). Chemical survey of Bahr El Bakar Drain system and its effects on Manzala Lake. In: Proceedings of the 2nd Egyptian Congress of Chemical Engineering, (pp. 1-10), Cairo, Egypt, March 18-20, 1984.

Salem, Sh, Hamed,Y., Sheshtawy, A, and Ali, A(2011). Environmental assessments for areas located both sides of Bar El-Baqar polluted drain northeastern Egypt. Article in Press

Shang, Y.C., Leung, P. \& Ling, B.H., (1998). Comparative economics of shrimp farming in Asia. Aquaculture 164 (1-4), 183-200.

U. S. Environmental Protection Agency, USEPA (1986). Test methods for evaluating solid waste: physical/chemical methods. SW-846. Washington, D. C.: USEPA, Office of Solid Waste and Emergency Response.

Zaki, M. M. M. (1994). Microbiological and toxicological study of the environmental pollution of Lake Manzala (108 pp). MSc Thesis, Faculty of Science, Suez Canal University, Ismailia, Egypt 


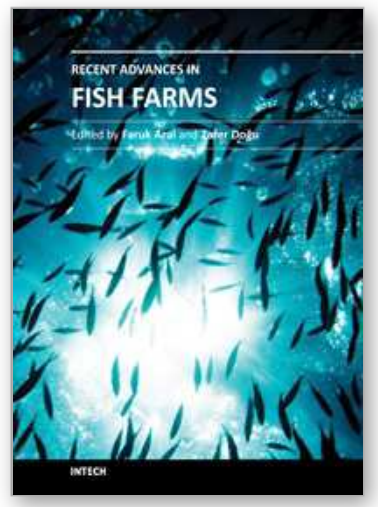

\author{
Recent Advances in Fish Farms \\ Edited by Dr. Faruk Aral
}

ISBN 978-953-307-759-8

Hard cover, 250 pages

Publisher InTech

Published online 21, November, 2011

Published in print edition November, 2011

The world keeps changing. There are always risks associated with change. To make careful risk assessment it is always needed to re-evaluate the information according to new findings in research. Scientific knowledge is essential in determining the strategy for fish farming. This information should be updated and brought into line with the required conditions of the farm. Therefore, books are one of the indispensable tools for following the results in research and sources to draw information from. The chapters in this book include photos and figures based on scientific literature. Each section is labeled with references for readers to understand, figures, tables and text. Another advantage of the book is the "systematic writing" style of each chapter. There are several existing scientific volumes that focus specially on fish farms. The book consists of twelve distinct chapters. A wide variety of scientists, researchers and other will benefit from this book.

\title{
How to reference
}

In order to correctly reference this scholarly work, feel free to copy and paste the following:

Y. Hamed, Sh. Salem, A. Ali and A. Sheshtawi (2011). Environmental Effect of Using Polluted Water in New/Old Fish Farms, Recent Advances in Fish Farms, Dr. Faruk Aral (Ed.), ISBN: 978-953-307-759-8, InTech, Available from: http://www.intechopen.com/books/recent-advances-in-fish-farms/environmental-effect-of-usingpolluted-water-in-new-old-fish-farms

\section{INTECH}

open science | open minds

\author{
InTech Europe \\ University Campus STeP Ri \\ Slavka Krautzeka 83/A \\ 51000 Rijeka, Croatia \\ Phone: +385 (51) 770447 \\ Fax: +385 (51) 686166 \\ www.intechopen.com
}

\author{
InTech China \\ Unit 405, Office Block, Hotel Equatorial Shanghai \\ No.65, Yan An Road (West), Shanghai, 200040, China \\ 中国上海市延安西路65号上海国际贵都大饭店办公楼 405 单元 \\ Phone: +86-21-62489820 \\ Fax: +86-21-62489821
}


(C) 2011 The Author(s). Licensee IntechOpen. This is an open access article distributed under the terms of the Creative Commons Attribution 3.0 License, which permits unrestricted use, distribution, and reproduction in any medium, provided the original work is properly cited. 